\title{
INFLUENCE OF THE SOLID WASTE LANDFILL OF KALININGRAD CITY ON ATMOSPHERE AND SOIL
}

\author{
Maria Vershinina \\ Kaliningrad Municipal Company "Chistota”, Russia
}

\begin{abstract}
The solid waste polygon of Kaliningrad City was established in 1978. According to Russian environment protection legislation a special internal program for an enterprise to monitor and control the impact on surface and underground water, air, soil, noise is necessary to be prepared. In 2001 KMC "Chistota" approved such a program and started to regularly make chemical analysis of surface water, soil and air.
\end{abstract}

\section{KEYWORDS}

Landfill; Solid waste; Environmental control; Surface and groundwater; Soil; Air.

\section{INTRODUCTION}

Household solid waste landfill of Kaliningrad is located on the west outskirt of the city and was established in 1978 as a temporal one until a specially equipped place was constructed. The territory of the landfill is 13.5 ha, closest accommodation area is in $1 \mathrm{~km}$. The forest surrounds the landfill. Pregol River flows on the east side; the ground of the landfill is waterlogged. Landfill has not any specially formed borders and look like an oval (Figure 1).

For the time being about $26 \mathrm{mln} . \mathrm{m}^{3}$ of waste were already accumulated in the landfill. Waste amount delivered to landfill is controlled visually. Card technology is used for waste distribution with interim waste isolation. Now the height of waste storage is $18-20 \mathrm{~m}$.

According to Russian environment protection legislation a special internal program (plan) for an enterprise to control the impact on surface and underground water, air, soil, noise is necessary to be prepared for environment quality estimation, for making prognosis on natural and anthropogenic factors impact. All aspects of the ecological monitoring for household waste landfill are institutionalized by sanitary rules SP 2.1.7.1038-01 Hygienic requirements to work out and support the household waste landfill approved by the Chief State Sanitary Doctor of the RFO in 30.05.2001.

In 2001, KMC "Chistota" responsible for city polygon designed such program of internal environmental control, and Chief State Sanitary Doctor of Kaliningrad proved that program. According to that program the soil samples are taken in one control point in $50 \mathrm{~m}$ from the landfill border. The air samples are taken in two points: first - in $400 \mathrm{~m}$ from the landfill border, second control point - about $1200 \mathrm{~m}$ from the landfill and near Kosmodemjansky village. Taking into account that there is opened city's collector for housing wastewater between the polygon and Kosmodemjansky suburb and car road Kaliningrad-Baltiysk the previous scheme of air samples taking could not characterize air emissions of polygon only. 
Therefore, since May 2003 air samples are taken near the check point of the landfill and in additional control point in $600 \mathrm{~m}$ from the landfill border, near enterprise AGA KAAZ (Figure l).

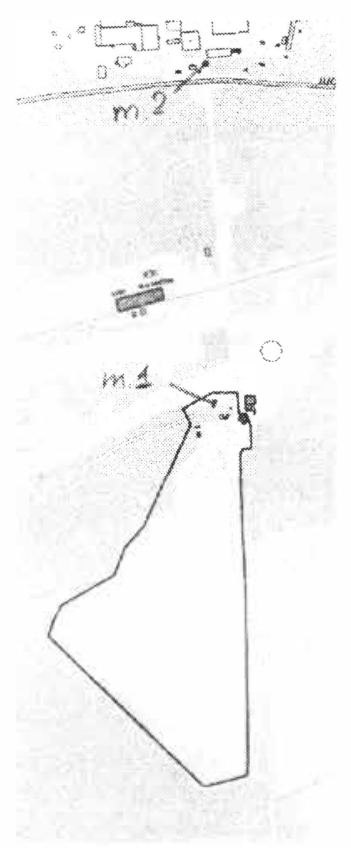

Figure 1: Enterprise AGA KAAZ

From 2001 to 2004, analyses were done twice a year, since 2004- every three months. According to the program the environmental control is done for checking the conditions of air and soil. Specialists of the Regional Center of Hygiene and Sanitary make air and soil samples for chemical analysis. The main measured parameters in air are grim, combustible gases (due to methane), benzyl, non-toxic dust, nitrogen oxide, carbon oxide, hydrogen sulfide, sulphur dioxide, ammonia, and vapors of mercury. The main measured parameters for soil are metals, oil products and microbiological analysis.

Samples are handled according to the actual normative Russian rules; values of the allowed levels of the pollutants are taken from Russian standards.

The results of the analyzed parameters of air samples for the period of May 2003 - July 2007 are shown in the Table 1. Table 2 shows the results of soil samples analysis from the, September 2003 -July 2007..During the monitoring period the commands of maximum allowed concentrations (MAC) were observed:

- 21.05.2003 in air samples for hydrogen sulfide in point $1-$ in 2.1 times, in point 2 in 2.2 times;

- 24.04. 2003 in soil samples for salts of heavy metals (zinc, chromium, lead, cuprum); 
- 12.07.2004 in air samples in point 1 for suspended compounds -in 2 times;

- 24.12.2004 in soil samples eggs and larvas of gelmints were observed;

- 14.04.2005 in soil samples enterococs were found;

- 10.10.2005 in air samples in point 1 for hydrogen oxide -in 4 times, for hydrogen sulfide - in 4 times;

- 07.08.2006 in air samples in point 1 for sulphur dioxide in 1.6 times, for hydrogen sulfide - in 2 times;

- 26.09.2006 in air samples in point 1 sulphur dioxide -in 6 times, for hydrogen sulfide in 3 times;

- 11.12.2006 in air samples in point 1 combustible gases -in 1.2 times;

- 30.03.2007 in air samples in point 1 for hydrogen sulfide - in 3.6 times.

Due to mentioned data commands of MACs for salts heavy metals in soil samples were noted and for sulphur dioxide, hydrogen sulfide, nitrogen dioxide and other pollutants in air samples as well.

Control for underground water conditions is not done because there are no control holes on the landfill.

Summing up it is necessary to note that housing solid waste polygon of the Kaliningrad is the only one landfill in the Kaliningrad Region where the internal environmental control with participation of the sanitary authorities organized. However, it is needed to drill control holes for underground water quality monitoring in zone of the landfill influence. And for more detailed research of the environmental impact it is necessary to increase the quantity and frequency of sampling air and soil in the zone of landfill influence.

We hope to collect and then use Swedish experience for waste landfill monitoring in the framework of the Tacis Project JOCCOW "Joint capacity building concerning waste management"(JOCCOW). 


\begin{tabular}{|c|c|c|c|c|c|c|c|c|c|c|c|c|c|c|c|c|}
\hline \multirow{2}{*}{$\begin{array}{c}\text { Name of } \\
\text { parameter }\end{array}$} & \multicolumn{16}{|c|}{ Day of samples taking and value of parameter } \\
\hline & 21.05 .03 & 31.10 .03 & 05.04 .04 & 12.07 .04 & 13.10 .04 & 16.12 .04 & 11.04 .05 & 11.07 .05 & 10.10 .05 & 22.12 .05 & 06.05 .06 & 07.08 .06 & 26.09 .06 & 11.12 .06 & 30.03.07 & 02.07.07 \\
\hline $\mathrm{CO}$ & 0,8 & 1,4 & 1,1 & 1,0 & 1,0 & 1,6 & 1,8 & 3,4 & 1,5 & 1,6 & 1,6 & 1,0 & 1,0 & 1,0 & 1,0 & 1,0 \\
\hline $\mathrm{N} 2 \mathrm{O}$ & 0,038 & 0,020 & 0,020 & 0,020 & 0,020 & 0,020 & 0,020 & 0,028 & 0,025 & 0,020 & 0,140 & 0,050 & 0,020 & 0,082 & 0,070 & 0,020 \\
\hline $\begin{array}{l}\text { Vapors of } \\
\mathrm{Hg}\end{array}$ & & 0,0001 & & $0,00(0) 1$ & 0,0001 & 0,0001 & 0,0002 & 0,0001 & 0,0002 & 0,0001 & 0,0001 & 0,0001 & 0,0001 & 0,0001 & 0,0001 & $(0,0001$ \\
\hline $\mathrm{NH} 4$ & 0,02 & 0,02 & $0,(12$ & 0,02 & 0,02 & 0,02 & 0,02 & 0,02 & 0,10 & 0,03 & 0,05 & 0,10 & 0,12 & 0,14 & 0,03 & 0,02 \\
\hline $\mathrm{H} 2 \mathrm{~S}$ & 0,017 & 0,004 & 0,006 & 0,008 & 0,004 & 0,004 & 0,004 & 0,007 & 0,032 & 0,007 & 0,004 & 0,016 & 0,025 & 0,004 & 0,029 & 0,004 \\
\hline $\begin{array}{l}\text { Suspended } \\
\text { compounds }\end{array}$ & 0,26 & & & 1,00 & & & 0,26 & 0,50 & & & 1,00 & 0,34 & 0,26 & & 0,26 & 0,26 \\
\hline $\mathrm{SO} 2$ & $(0,050$ & 0,050 & 0,025 & 0,025 & 0,025 & 0,097 & $(0,250)$ & $(0,450)$ & $(0,500)$ & 0,120 & $(0,150$ & $(0,800$ & 3,020 & 0,025 & 0,050 & 0,300 \\
\hline Grim & & 0,025 & 0,025 & & 0,025 & $(0,025$ & & & $(0,025$ & 0,050 & & & $(0,(025$ & $0,(050)$ & $(0,025$ & $(0,025$ \\
\hline $\mathrm{NO}$ & & & $0,(030$ & $0,(030$ & 0,030 & $(0,030$ & 0,030 & 0,030 & 1,600 & $0,(030$ & 0,046 & 0,200 & 0,220 & 0,190 & 0,045 & 0,032 \\
\hline Benzyl & & & & $0,0(0)$ & & & & $(0,030)$ & & & $(0,150$ & & $0,(070$ & & $(0,180$ & $(0,170$ \\
\hline $\begin{array}{l}\text { Combustible } \\
\text { gases }\end{array}$ & 25,0 & & 40,0 & 40,0 & & & 40,0 & $40,()$ & & & 40 & 40) & 40) & 63,7 & & \\
\hline
\end{tabular}




\begin{tabular}{|c|c|c|c|c|c|c|c|c|c|c|c|c|c|c|c|c|c|}
\hline \multirow[b]{2}{*}{$\begin{array}{c}\text { Name of } \\
\text { parameter }\end{array}$} & \multicolumn{17}{|c|}{ Day of samples taking and value of parameter } \\
\hline & $\begin{array}{c}25.09 . \\
01\end{array}$ & $\begin{array}{c}05.05 .0 \\
2\end{array}$ & $\begin{array}{c}24.04 . \\
03\end{array}$ & $\begin{array}{c}23.10 . \\
03\end{array}$ & $\begin{array}{c}08.04 . \\
04\end{array}$ & $\begin{array}{c}26.07 \\
04\end{array}$ & $\begin{array}{c}24.12 . \\
04\end{array}$ & $\begin{array}{c}14.04 .0 \\
5\end{array}$ & $\begin{array}{c}04.08 .0 \\
5 \\
\end{array}$ & $\begin{array}{c}13.10 .0 \\
5\end{array}$ & $\begin{array}{c}30.12 .0 \\
5\end{array}$ & $\begin{array}{c}09.06 .0 \\
6 \\
\end{array}$ & $\begin{array}{c}29.09 .0 \\
6 \\
\end{array}$ & $\begin{array}{c}02.11 .0 \\
6\end{array}$ & $\begin{array}{c}14.12 .0 \\
6\end{array}$ & $\begin{array}{c}04.04 .0 \\
7 \\
\end{array}$ & $\begin{array}{c}05.07 . \\
07\end{array}$ \\
\hline $\mathrm{pH}$ & 6,15 & 6,86 & 7,67 & 7,12 & 7,14 & 6,72 & 6,97 & 6,30 & 6,52 & 6,84 & 6,88 & 6,40 & 6,89 & 6,94 & 6,95 & 6,79 & 6,80 \\
\hline Oil products & 0,35 & $(0,12$ & 1,68 & & $(0,41$ & 17,00 & 41,30 & 38,10 & 4()$, 9()$ & $73,0()$ & 45,30 & 0,26 & 57,40 & 81,00 & 57,40 & 33,80 & $36,8()$ \\
\hline Cupper & 4,00 & 6,50 & $194,0()$ & $46,5()$ & 2,30 & $\begin{array}{r}490(0,0) \\
0\end{array}$ & $4,7()$ & $(0,9()$ & 24,50 & $9,8()$ & 19,30 & 541,00 & 3,00 & $(0,80$ & 1,00 & 1,40 & 2,10 \\
\hline Zinc & 16,50 & 45,00 & 760,00 & 16,00 & 9,20 & 810,00 & 26,00 & 7,20 & 11,00 & 15,30 & 45,00 & 144,00 & $5,(0)$ & $4,0()$ & 8,20 & 6,10 & 4,60 \\
\hline Chromium & 1,50 & $1,8()$ & 29,50 & 1,40 & 1,20 & 3,60 & 0,80 & $(0,80$ & $(0,80$ & 0,80 & 0,80 & $1,4()$ & $(0,80$ & 0,80 & 0,80 & 0,80 & 0,80 \\
\hline Nickel & $(0,80$ & $2,8()$ & $15,00)$ & $(0,80$ & $(0,80$ & $2,(0)$ & $(0,80$ & $(0,80$ & 0,80 & $(0,80$ & $(0,80$ & 1,20 & 0,80 & 0,80 & $(0,80$ & $(0,80$ & $(0,80$ \\
\hline Lead & 10,50 & $12,(0)$ & $201,(0)$ & 0,20 & $2,(0)$ & $83,(0)$ & 6,80 & 2,50 & 17,50 & $6,(0)$ & 9,50 & $23,(0)$ & $3,9()$ & 2,50 & 2,00 & 4,20 & 4,50 \\
\hline Cadımium & 0,20 & 0,20 & $(0,40$ & 0,20 & 0,20 & 0,50 & 0,20 & 0,20 & 0,20 & 0,20 & $(0,20$ & $(0,20$ & 0,20 & $(0,20$ & 0,20 & 0,20 & $(0,20$ \\
\hline $\begin{array}{l}\text { Eggs and } \\
\text { larvas of gel } \\
\text { mints }\end{array}$ & & & & & & & $\begin{array}{l}\text { observ } \\
\text { ed }\end{array}$ & & & & & & & & & & \\
\hline Enterococs & & & & 0,50 & $(0,50$ & $(0,50$ & $2,3()$ & $23,(0)$ & 0,50 & 2,30 & $(0,50$ & $(0,50$ & 0,50 & & $(0,5$ & $9,(0)$ & $1,(0)$ \\
\hline $\begin{array}{l}\text { Bacterias of } \\
\text { enteric rod } \\
\text { group }\end{array}$ & & & & $1,(0)$ & 10,00 & 1,00 & 10,00 & 10,00 & 1,00 & 10,00 & 0,50 & $1,0()$ & 10,00 & & 10,00 & $21,0()$ & 1,00 \\
\hline
\end{tabular}


Kalmar ECO-TECH '07

KALMAR, SWEDEN, November 26-28, 2007

\section{REFERENCES}

[1] СП 2.1.7.1038-01 «Гигиенические требования к устройству и содержанию полигонов для твердых бытовых отходов».

[2] Инструкция по проектированию, эксплуатации и рекультивации полигонов для твердых бытовых отходов, АКХ им. К.Д. Памфилова, М. 1996 г.

[3] Протоколы анализов почвы и атмосферного воздуха в зоне влияния полигона ТБО г. Калининграда 